OPEN ACCESS

Edited by:

Fernando Carlos Gómez-Merino, Colegio de Postgraduados, Mexico

Reviewed by:

Susan Tandy,

ETH Zurich, Switzerland

Daniel Pergament Persson, University of Copenhagen, Denmark

*Correspondence:

Miao Li

miaoli@ustc.edu.cn Linxi Yuan

yuanli@ustc.edu.cn

Specialty section: This article was submitted to Plant Nutrition, a section of the journal

Frontiers in Plant Science

Received: 20 February 2016 Accepted: 28 November 2016 Published: 15 December 2016

Citation:

Wu Z, Yin X, Bañuelos GS, Lin Z-Q,

Liu Y, Li M and Yuan L (2016) Indications of Selenium Protection against Cadmium and Lead Toxicity in Oilseed Rape (Brassica napus L.).

Front. Plant Sci. 7:1875

doi: 10.3389/fpls.2016.01875

\section{Indications of Selenium Protection against Cadmium and Lead Toxicity in Oilseed Rape (Brassica napus L.)}

\author{
Zhilin Wu $u^{1,2,3}$, Xuebin Yin ${ }^{2,3,4}$, Gary S. Bañuelos ${ }^{5}$, Zhi-Qing Lin ${ }^{6}$, Ying Liu' ${ }^{2,3,4}$, Miao Li ${ }^{1,4,7 *}$ \\ and Linxi Yuan ${ }^{2,3,4 *}$ \\ ${ }^{1}$ Key Laboratory of Agri-Food Safety of Anhui Province, Scientific Observing and Experimental Station of Agricultural \\ Environment of the Ministry of Agriculture - Laboratory of Quality and Safty Risk Assessment for Agricultural Products on \\ Storage and Preservation of the Ministry of Agriculture, School of Plant Protection - School of Resources and Environment, \\ Anhui Agricultural University, Hefei, China, ${ }^{2}$ School of Earth and Space Sciences, University of Science and Technology of \\ China, Hefei, China, ${ }^{3}$ Jiangsu Bio-Engineering Research Centre of Selenium, Suzhou Institute for Advanced Study, University \\ of Science and Technology of China, Suzhou, China, ${ }^{4}$ Institute of Advanced Technology, University of Science and \\ Technology of China, Hefei, China, ${ }^{5}$ San Joaquin Valley Agricultural Sciences Center, United States Department of \\ Agriculture - Agricultural Research Service, Parlier, CA, USA, ${ }^{6}$ Environmental Sciences Program and Department of \\ Biological Sciences, Southern Illinois University Edwardsville, Edwardsville, IL, USA, ${ }^{7}$ The Northwest of Anhui Province \\ Station for Integrative Agriculture, Research Institute for New Rural Development, Anhui Agricultural University, Hefei, China
}

The present study investigated the beneficial role of selenium (Se) in protecting oilseed rape (Brassica napus L.) plants from cadmium $\left(\mathrm{Cd}^{+2}\right)$ and lead $\left(\mathrm{Pb}^{+2}\right)$ toxicity. Exogenous Se markedly reduced $\mathrm{Cd}$ and $\mathrm{Pb}$ concentration in both roots and shoots. Supplementation of the medium with $\mathrm{Se}\left(5,10\right.$, and $\left.15 \mathrm{mg} \mathrm{kg}^{-1}\right)$ alleviated the negative effect of $\mathrm{Cd}$ and $\mathrm{Pb}$ on growth and led to a decrease in oxidative damages caused by $\mathrm{Cd}$ and $\mathrm{Pb}$. Furthermore, Se-enhanced superoxide free radicals $\left(\mathrm{O}_{2}^{\overline{\mathbf{\theta}}}\right)$, hydrogen peroxide $\left(\mathrm{H}_{2} \mathrm{O}_{2}\right)$, and lipid peroxidation, as indicated by malondialdehyde accumulation, but decreased superoxide dismutase and glutathione peroxidase activities. Meanwhile, the presence of $\mathrm{Cd}$ and $\mathrm{Pb}$ in the medium affected Se speciation in shoots. The results suggest that $\mathrm{Se}$ could alleviate $\mathrm{Cd}$ and $\mathrm{Pb}$ toxicity by preventing oxidative stress in oilseed rape plant.

Keywords: selenium, cadmium, lead, oxidative stress, oilseed rape (Brassica napus L.), antioxidant defense system

\section{INTRODUCTION}

Protection against the accumulation and toxic effects of heavy metals on humans, animals, and plants are topics of current interest due to the increasing emission of pollutants resulting from industries and anthropogenic activities (Hall, 2002; Filek et al., 2008, 2010; Cartes et al., 2010; Feng et al., 2013). Cadmium (Cd) and lead ( $\mathrm{Pb}$ ) are harmful heavy metals pollutants in soils and water, and pose health risk for humans through the food chain due to their plant-availability in soils (He et al., 2004; Belkhadi et al., 2010; Filek et al., 2010; Gallego et al., 2012; Lin et al., 2012; Saidi et al., 2014). The deleterious effects of $\mathrm{Cd}$ and $\mathrm{Pb}$ to plants and other organisms have previously been investigated (Belzile et al., 2006; Tang et al., 2015). Plant species and varieties show large differences in heavy metals tolerance, from metal high-sensitivity to metal hyperaccumulation and hypertolerance phenotypes in plants (Metwally et al., 2003; Popova et al., 2009; 
Belkhadi et al., 2010; Saidi et al., 2014). To avoid phytotoxicity of heavy metals, plants adopt different defense strategies including the production of metallothioneins (MTs) and phytochelatins (PCs) (Lin et al., 2012; Saidi et al., 2014; Qing et al., 2015). One of the protective mechanisms employed is the induction of the antioxidant defense system, which involves the sequential and simultaneous action of a number of enzymes such as peroxidase (POD), catalase (CAT), superoxide dismutase (SOD), ascorbate peroxidase (APX), and non-enzymatic scavengers such as glutathione (GSH) and ascorbate (AsA). The latter are responsible for scavenging excessively accumulated reactive oxygen species (ROS) in plants under stress conditions (Lin et al., 2012; Saidi et al., 2014; Qing et al., 2015). Cadmium and $\mathrm{Pb}$ could cause oxidative damage to plants, directly or indirectly through the generation of ROS (Lin et al., 2012; Khan et al., 2015). Others have found that $\mathrm{Cd}$ and $\mathrm{Pb}$ cause toxicity, which affects plant growth, development, and metabolisms, as well as other physiological processes, including inhibition of seed germination, alteration of enzymatic function, impaired photosynthesis, membrane damage (Schützendübel and Polle, 2002; Shekhawat et al., 2010; Feng et al., 2013; Irfan et al., 2014). Therefore, it is of vital importance to develop reliable approaches such as plant breeding and chemical regulators to prevent heavy metals accumulation in plants. Among them, the application of chemical regulators to alleviate heavy metal toxicity and reduce plant heavy metal uptake in farmland contaminated with heavy metals, might be a practical and cost-effective strategy for sustainable utilization of natural resources and production of safe, high-quality agro-products. (Lin et al., 2012; Noriega et al., 2012; Cao et al., 2013; Ali et al., 2015).

Selenium (Se) is an essential trace element for humans and animals, and some findings suggest that Se may be a beneficial element, which plays a novel role in plant biology for innovative crop production (Trumble et al., 1998; Rayman, 2000; Terry et al., 2000; Ellis and Salt, 2003; Hartikainen, 2005; Pilon-Smits et al., 2009; Zhu et al., 2009; Bañuelos et al., 2011; Hatfield et al., 2014; Wu et al., 2015). Selenium at low concentrations exerts positive effects for plants such as promoting growth, increasing antioxidative capacity, improving yield and quality, and delaying ripening and senescence (Hartikainen et al., 2000; Xue et al., 2001; Turakainen et al., 2004; Broadley et al., 2010; Pukacka et al., 2011; Pezzarossa et al., 2012). Applying Se fertilizer as base fertilizer or foliar spray has been used to increase the Se content in the edible portion of crops and to simultaneously counteract the detrimental effects of diverse environmental stresses, such as heavy metals, water, drought, salt, high temperature, UV radiation, senescence, pathogens, and insect pests (Hartikainen et al., 2000; Pennanen et al., 2002; Hanson et al., 2003; Djanaguiraman et al., 2005, 2010; Germ et al., 2005; Broadley et al., 2010; Yao et al., 2010; Zembala et al., 2010; Hasanuzzaman and Fujita, 2011; Hasanuzzaman et al., 2011; Pukacka et al., 2011; Kumar et al., 2012; Pezzarossa et al., 2012; Feng et al., 2013; Ardebili et al., 2014; Ahmad et al., 2016; Kaur et al., 2016; Wu et al., 2016).

Recently, the beneficial role of Se in alleviation of heavy metalinduced oxidative stress has been well established (Filek et al., 2008, 2010; Han et al., 2015). The vital role of Se in antioxidant protection from heavy metal stress has been observed in different biological systems (Yathavakilla and Caruso, 2007; Kumar et al., 2012; Lin et al., 2012; Malik et al., 2012) including some crop plants (Lin et al., 2012; Mroczek-Zdyrska and Wojcik, 2012; Mozafariyan et al., 2014). Others have recognized that Se can detoxify many toxic heavy metals such as $\mathrm{Cd}, \mathrm{Pb}$, chromium $(\mathrm{Cr})$, and arsenic (As) in plants (Shanker et al., 1996a,b; Srivastava et al., 1998; Feng et al., 2013; Saidi et al., 2014; Qing et al., 2015). Though many studies have demonstrated that external Se may act as a chemical regulator to reduce heavy metal-induced oxidative stress, a better understanding of the mode of action of Se in prevention of heavy metal accumulation in plants should be achieved. Moreover, the possible mechanisms of the Se-enhanced tolerance and/or resistance of plants to $\mathrm{Cd}$ and $\mathrm{Pb}$ stresses remain unclarified. The present study was undertaken to investigate the potential role of external $\mathrm{Se}$ in modulating $\mathrm{Cd} / \mathrm{Pb}$-induced oxidative stress and $\mathrm{Cd} / \mathrm{Pb}$ uptake/translocation in oilseed rape plant. We aim to provide a basis for developing strategies to reduce risks associated with $\mathrm{Cd}$ and $\mathrm{Pb}$ toxicity and maintaining sustainable crop production.

\section{MATERIALS AND METHODS}

\section{Plant Material, Soil Collection, and Experimental Designs}

Potting compost was used in the experiment and brought from Huai'an Hongyang Agricultural Technology Co. The soil's main properties were as follows: $\mathrm{N}+\mathrm{P}_{2} \mathrm{O}_{5}+\mathrm{K}_{2} \mathrm{O} \geq 2 \%$, contents of organic matter $\geq 40 \%$. Eight kilogram "HONGYANG" potting compost soil was weighed and loaded into a plastic pot $(10 \mathrm{~L}$, $20 \mathrm{~cm}$ height). The pot culture experiments were conducted in a greenhouse at the Suzhou Campus, the University of Science and Technology of China, Suzhou, China, under natural light conditions. Oilseed rape seeds (Brassica napus L. cv. Wanyou 18) were germinated and the seedlings were grown in the soil. After 6 weeks of growth, morphologically similar and healthy seedlings were selected and transplanted into the pots. The experiment had a completely randomized design with three replicates. Each replicate consisted of five plants per pot, and only two plants from each pot were selected for final harvest. The seedlings were allowed to grow for 15 days in the pots for acclimatization. After 15 days of growth, treatment were applied as follows: (a) Se as sodium selenite alone $(0,1,5,10$, 15, $20 \mathrm{mg} \mathrm{kg}^{-1}$ ), (b) Cd as cadmium chloride alone (1 or $5 \mathrm{mg}$ $\left.\mathrm{kg}^{-1}\right)$, and combined with Se as sodium selenite $(0,1,5,10$, $15,20 \mathrm{mg} \mathrm{kg}^{-1}$ ), respectively, (c) $\mathrm{Pb}$ as lead acetate alone (300 or $500 \mathrm{mg} \mathrm{kg}^{-1}$ ), and combined with $\mathrm{Se}$ as sodium selenite $\left(0,1,5,10,15,20 \mathrm{mg} \mathrm{kg}^{-1}\right)$, respectively. The Se concentrations were selected based upon a previous study (Saidi et al., 2014), while $\mathrm{Pb}$ and $\mathrm{Cd}$ concentrations were selected on the basis of national soil environmental quality standard (GB15618-1995) and the current levels of soil metal pollution in China. Plant samples were collected 40,60, 80, and 100 days after treatment at seedling stage, immediately immersed in liquid nitrogen and stored frozen at $-80^{\circ} \mathrm{C}$ for further analyses or directly used for various biochemical assays. 


\section{Determination of $\mathrm{Se}, \mathrm{Pb}$, and $\mathrm{Cd}$ Concentrations in Oilseed Rape Plants}

The sample preparation and the measurement of total Se were performed according to the methods of Lin et al. (2012) and Saidi et al. (2014). After plant samples were thoroughly washed with water, roots were soaked in $20 \mathrm{mM}$ EDTA for $15 \mathrm{~min}$ to remove adsorbed metals on the root surfaces and rinsed with distilled water (Barton and Abadia, 2006; Su et al., 2014), plant samples were oven-dried at $50^{\circ} \mathrm{C}$ for $48 \mathrm{~h}$ and ground to pass through a $0.2 \mathrm{~mm}$ sieve. $2.0 \mathrm{~g}$ samples were weighed into a $50 \mathrm{~mL}$ conical flask and $10 \mathrm{~mL}$ of concentrated $\mathrm{HNO}_{3}$ and $\mathrm{HClO}_{4}(4: 1, \mathrm{v} / \mathrm{v})$ were added to each flask. After a series of temperature programming and acid digestion at $100^{\circ} \mathrm{C}, \mathrm{HNO}_{3}$ was expelled completely and the volume of solution was approximately $2 \mathrm{~mL}$. Then $5 \mathrm{~mL} \mathrm{HCl}$ $(12 \mathrm{M})$ was added to reduce Se (VI) to Se (IV) for 3-4 h and the digestion solution was brought up to $25 \mathrm{~mL}$ for Se analysis. The total Se concentration was determined by Hydride Generation-Fluorescence Spectrometry (HG-AFS 9230; Beijing Titan Instrument Co., China).

Concentrations of $\mathrm{Pb}$ and $\mathrm{Cd}$ were measured by the method of Determination of Lead in Foods (China GB 5009.122010 National Food Safety Standard) and Determination of Cadmium in Foods (China GB 5009.15-2003 National Food Safety Standard) with some modifications. $1.0 \mathrm{~g}$ samples were digested in fired porcelain crucibles and dry ashed in a muffle furnace $6-8 \mathrm{~h}$ at $500^{\circ} \mathrm{C}$, and then cooled. The ash content was dissolved in $\mathrm{HNO}_{3}(0.5 \mathrm{M})$ and the digestion solution was diluted to $25 \mathrm{~mL}$ prior to $\mathrm{Pb}$ and $\mathrm{Cd}$ analysis. Concentrations of $\mathrm{Cd}$ and $\mathrm{Pb}$ in the roots and shoot samples were analyzed by atomic absorption spectroscopy (PerkinElmer AA-700, Shanghai PerkinElmer Inc., China) with graphite furnace.

\section{Assay for Antioxidative Enzyme Activities}

To determine enzyme activity after different treatments, fresh whole shoots of oilseed rape were homogenized in $8 \mathrm{~mL}$ $50 \mathrm{mM}$ PBS (pH 7.8) using a prechilled mortar and pestle, and subsequently centrifuged at $10,000 \times g$ for $15 \mathrm{~min}$ at $4^{\circ} \mathrm{C}$. The supernatant was used for the assays of antioxidative enzyme activity. SOD activity was determined as described by Lin et al. (2012) and Saidi et al. (2014). Glutathione peroxidase (GPx) activity was measured using modification of the procedure by Saidi et al. (2014) and Ali et al. (2015).

\section{Determination of $\mathrm{H}_{2} \mathrm{O}_{2}$ and $\mathrm{O}_{2}^{-}$and Lipid Peroxidation}

One gram fresh shoots of oilseed rape plants was ground together with phosphate buffer ( $\mathrm{pH}$ 7.0) and a small quantity of quartz sand in liquid nitrogen. The homogenate was centrifuged at $10000 \times g$ for $15 \mathrm{~min}$ and the supernatant was used for determination of hydrogen peroxide $\left(\mathrm{H}_{2} \mathrm{O}_{2}\right)$ and superoxide anion $\left(\mathrm{O}_{2}^{\overline{\boldsymbol{\sigma}}}\right)$. Hydrogen peroxide production rate was determined with the method by Lin et al. (2012) and Saidi et al. (2014). Superoxide anion production rate was determined with the method by Lin et al. (2012) and Qing et al. (2015). The level of lipid peroxidation in plant tissues was determined as 2-thiobarbituric acid (TBA) reactive metabolites, mainly malondialdehyde (MDA) with the method by Lin et al. (2012) and Qing et al. (2015).

\section{Chemical Speciation Analysis of Se in Shoots of Oilseed Rape Plant}

Analysis of Se speciation was performed according to the method by Bañuelos et al. (2011) and Yuan et al. (2013). The whole shoots were extracted with $100 \mathrm{mM}$ Tris-HCl buffer ( $\mathrm{pH}$ 7.5) in an ultrasonic tank for $10 \mathrm{~min}$ and then enzyme Protease XIV was then added to shake for $24 \mathrm{~h}$ at $37^{\circ} \mathrm{C}$. After extraction, the mixture was centrifuged at $10000 \times g$ for $30 \mathrm{~min}$ at $4^{\circ} \mathrm{C}$. The supernatant was collected and filtered through a $0.22 \mathrm{~mm}$ filter prior to Se speciation analysis. A Hamilton PRP X-100 anion exchange column $(4.1 \mathrm{~mm} \times 250 \mathrm{~mm} \times 10 \mu \mathrm{m})$ was used to separate different Se compounds. The mobile phase was $40 \mathrm{mM}$ $\mathrm{NH}_{4} \mathrm{H}_{2} \mathrm{PO}_{4}\left(\mathrm{pH}\right.$ 6.0) with a flow rate of $1 \mathrm{~mL} \mathrm{~min}^{-1}$. The eluent from the column was mixed with concentrated $\mathrm{HCl}$ and then passed through the UV unit. $1.2 \% \mathrm{NaBH}_{4}$ in $0.1 \mathrm{~mol} \mathrm{~L}^{-1} \mathrm{NaOH}$ was added after the UV unit. Argon was used as carrier gas to transfer $\mathrm{H}_{2}$ from the gas liquid separator through the dryer into the AFS detector. The dryer gas was nitrogen with a flow rate of $3 \mathrm{~L} \mathrm{~min}-1$. Then, Se species in shoots of oilseed rape plant were detected by LC-UV-HG-AFS system (Beijing Jitian instruments Co., Ltd, China).

\section{Statistical Analysis}

The experiment was replicated three times under the same conditions. All statistical analyses were performed using the SPSS software version 13.0 (SPSS Inc., Chicago, IL, USA). Significant differences between treatment effects were determined by one way ANOVA followed by Duncan's multiple range test for multiple comparisons with statistical significance of $p \leq 0.05$.

\section{RESULTS}

\section{Effects of Exogenous $\mathrm{Se}$ on $\mathrm{Pb}$ and $\mathrm{Cd}$ Accumulation in Oilseed Rape Seedlings}

The Se concentration in the shoots increased significantly with increasing Se level in the soil from 0 to $15 \mathrm{mg} \mathrm{kg}^{-1}$ in the soil (Figure 1) $(p \leq 0.05)$. However, the Se concentration in the plant tissue was reduced to $10.31 \mathrm{mg} \mathrm{kg}^{-1}$ when Se addition was from 15 to $20 \mathrm{mg} \mathrm{kg}^{-1}$. In addition, Se at $10 \mathrm{mg} \mathrm{kg}^{-1}$ significantly decreased the $\mathrm{Cd}$ and $\mathrm{Pb}$ concentrations in the oilseed rape (Figures 2 and 3$)(p \leq 0.05)$.

The concentrations of $\mathrm{Cd}$ and $\mathrm{Pb}$ in the roots significantly decreased with increasing Se treatment level, suggesting that Se inhibited $\mathrm{Cd}$ and $\mathrm{Pb}$ accumulation in roots and consequently further reduced heavy metal toxic effects in shoots (Figure 4). Compared with the control, the Se treatment of $15 \mathrm{mg} \mathrm{kg}^{-1}$ reduced the root $\mathrm{Cd}$ concentration by $84.3 \%$ (Figure $4 \mathrm{~A}$ ), while the root $\mathrm{Pb}$ concentration was reduced by $66.3 \%$ at the $\mathrm{Se}$ treatment of $20 \mathrm{mg} \mathrm{kg}^{-1}$ (Figure 4B) $(p \leq 0.05)$. The reduction of $\mathrm{Cd}$ and $\mathrm{Pb}$ concentrations in roots was much greater than in the shoots $(p \leq 0.05)$. 


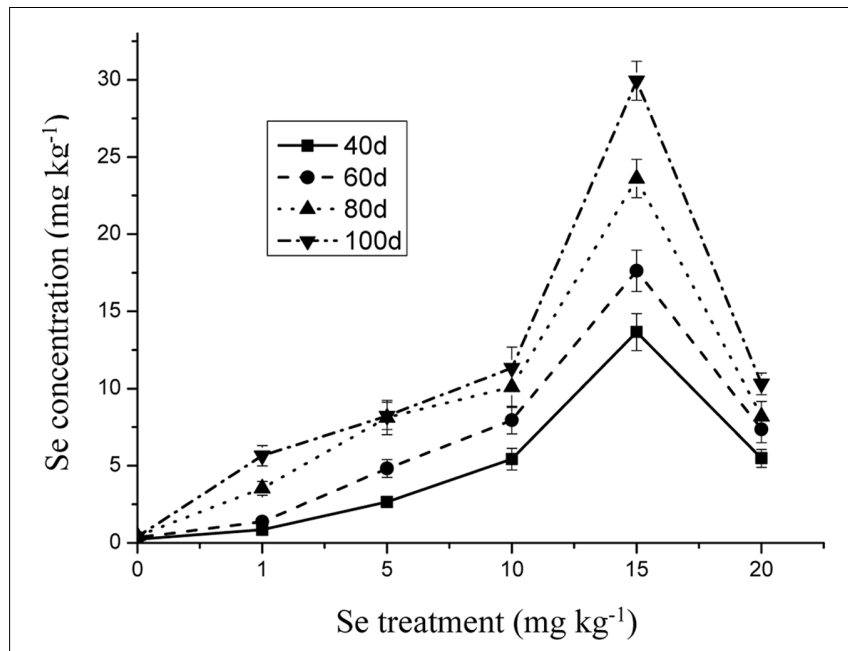

FIGURE 1 | Concentration of Se in shoots of oilseed rape treated with soil Se in different periods. Average concentrations (Dry biomass weight, DBW) provided with error bars representing the standard error. $(p \leq 0.05)$.

\section{Effects of Se on Antioxidant Enzymes Activities}

Selenium supplementation resulted in a significant decrease in antioxidative enzymes activities in the shoots upon $\mathrm{Cd}$ and $\mathrm{Pb}$ exposure. Moreover, SOD and GPx activities in the shoots were strongly affected by the Se treatment of $15 \mathrm{mg} \mathrm{kg}^{-1}$. However, a significant decrease in GPx and SOD activities in the shoots was observed at $20 \mathrm{mg} \mathrm{kg}^{-1} \mathrm{Se}$ (Figures 5A,B) $(p \leq 0.05)$.

\section{Effects of Se on Malondialdehyde, $\mathrm{H}_{2} \mathrm{O}_{2}$, and $\mathrm{O}_{2}^{-}$}

An accumulation of lipid peroxides is indicative of enhanced production of ROS. The level of MDA, one of the major TBA reactive metabolites, increased by $31 \%$ in the $500 \mathrm{mg} \mathrm{kg}^{-1} \mathrm{~Pb}$ treated shoots and by $43 \%$ in the $5 \mathrm{mg} \mathrm{kg}^{-1} \mathrm{Cd}$-treated shoots compared to control (Figure 6A) $(p \leq 0.05)$. Furthermore, the Se treatment of $1 \mathrm{mg} \mathrm{kg}^{-1}$ did not significantly influence the MDA level, while $15 \mathrm{mg} \mathrm{kg}^{-1}$ Se decreased the lipid peroxidation by $33 \%$ compared to control. In addition, the Se treatment had a significant effect against lipid peroxidation in the shoots, especially in the $\mathrm{Cd}$ treated group. The same tendency also appeared on the change of $\mathrm{H}_{2} \mathrm{O}_{2}$ levels and $\mathrm{O}_{2}^{-}$activities. The addition of $\mathrm{Se}$ at $10-15 \mathrm{mg} \mathrm{kg}^{-1}$ lessened the generation of $\mathrm{H}_{2} \mathrm{O}_{2}$ levels and $\mathrm{O}_{2}^{\overline{-}}$ activities induced by $\mathrm{Pb}$ and $\mathrm{Cd}$. (Figures 6B,C).

\section{Speciation of Se in Plant Tissues}

The extraction efficiency of total Se was between 8 and $29 \%$ in the oilseed rape shoots (Table 1). SeCys2 and SeMeCys were not found in shoots of oilseed rape plant under current detection conditions. SeMet was the major form of Se detected and accounted for $8-27 \%$ ( $p \leq 0.05)$. Moreover, approximately $5 \% \mathrm{Se}(\mathrm{IV})$ was detected in the $\mathrm{Se}+\mathrm{Pb}$ treatments.

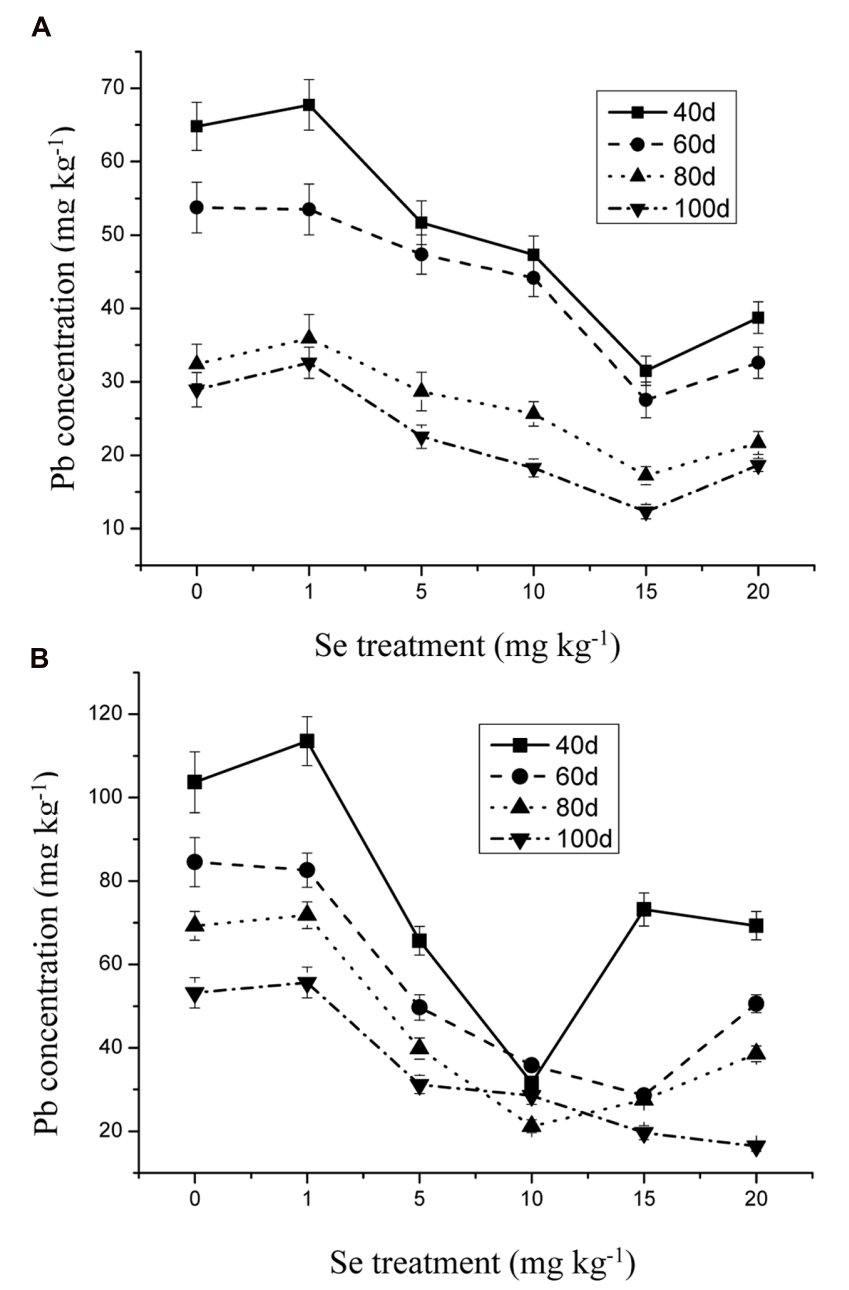

FIGURE 2 | (A) Concentration of $\mathrm{Pb}$ in shoots of oilseed rape treated with soil $\mathrm{Se}$ and $300 \mathrm{mg} \mathrm{kg}^{-1} \mathrm{~Pb}$ in different periods. (B) Concentration of $\mathrm{Pb}$ in shoots of oilseed rape treated with soil Se and $500 \mathrm{mg} \mathrm{kg}^{-1} \mathrm{~Pb}$ in different periods. Average concentrations (Dry biomass weight, DBW) provided with error bars representing the standard error. $(p \leq 0.05)$.

\section{DISCUSSION}

Heavy metal contamination is a major concern worldwide, hence strategies for protecting human and environmental health from heavy metals contaminants are of high priority (Gallego et al., 2012; Lin et al., 2012; Qing et al., 2015). The breeding of plant cultivars and the application of chemical regulators in order to reduce heavy metal uptake and accumulation may alleviate heavy metals toxicity in plants and improve crop quality by increasing the concentrations of beneficial trace elements (Grant et al., 2008; Feng et al., 2013; Ali et al., 2015; Kaur et al., 2016). The beneficial role of Se in alleviation of heavy metal-induced oxidative stress is well established, and the alleviating effects of Se on heavy metal toxicity to plants by decreasing uptake of $\mathrm{Hg}, \mathrm{As}, \mathrm{Cd}, \mathrm{Cr}$, and $\mathrm{Pb}$ have been reported (Feng et al., 2013; Saidi et al., 2014). Moreover, in the presence of phytotoxic levels of heavy metals, proper supplementation with Se may alleviate growth inhibition 


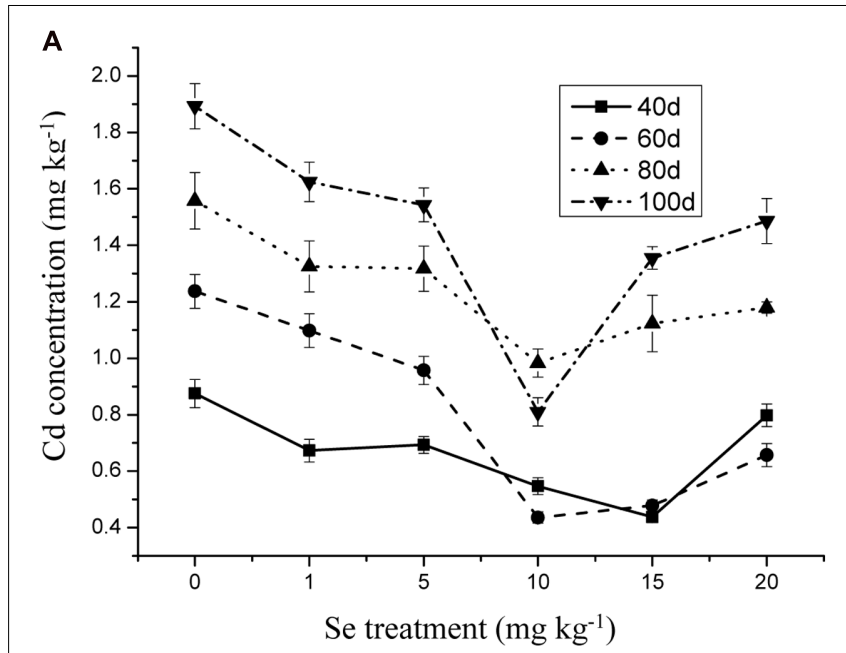

B

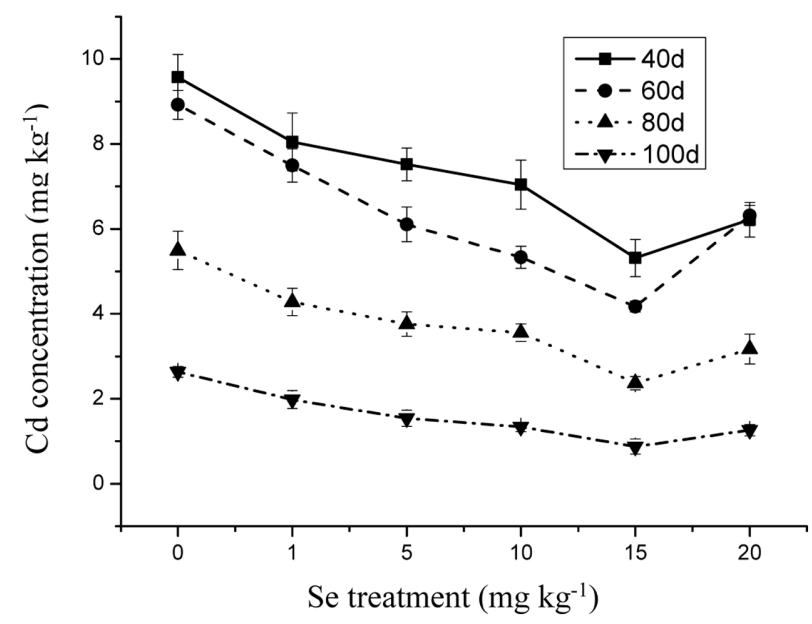

FIGURE 3 | (A) Concentration of Cd in shoots of oilseed rape treated with soil Se and $1 \mathrm{mg} \mathrm{kg}^{-1} \mathrm{Cd}$ in different periods. (B) Concentration of $\mathrm{Cd}$ in shoots of oilseed rape treated with soil Se and $5 \mathrm{mg} \mathrm{kg}^{-1} \mathrm{Cd}$ in different periods. Average concentrations (Dry biomass weight, DBW) provided with error bars representing the standard error. $(p \leq 0.05)$.

(Filek et al., 2008, 2010; Feng et al., 2013). The present study demonstrates the beneficial role of $\mathrm{Se}$ in reducing $\mathrm{Cd}$ and $\mathrm{Pb}$ uptake and toxicity by preventing oxidative stress in oilseed rape plants (Figures 2-4).

Selenium, an essential element for animals and humans, has also been found to be beneficial to plants (Ellis and Salt, 2003; Wu et al., 2015). However, Se often exerts a dual effect on plant growth. At low doses, it can stimulate the growth of plants and counteract many types of environmental stresses, including heavy metals, whereas at high levels, it can be toxic and cause oxidative damage to plants and other biota (Lin et al., 2012; Feng et al., 2013; Saidi et al., 2014; Qing et al., 2015). Although most higher plants do not require Se, the supplementation of Se fertilizers with sodium selenate or sodium selenite can positively affect the whole food chain from soil to plants, animals, and humans (Hartikainen, 2005; Lin et al., 2012; Feng et al., 2013; Saidi et al.,

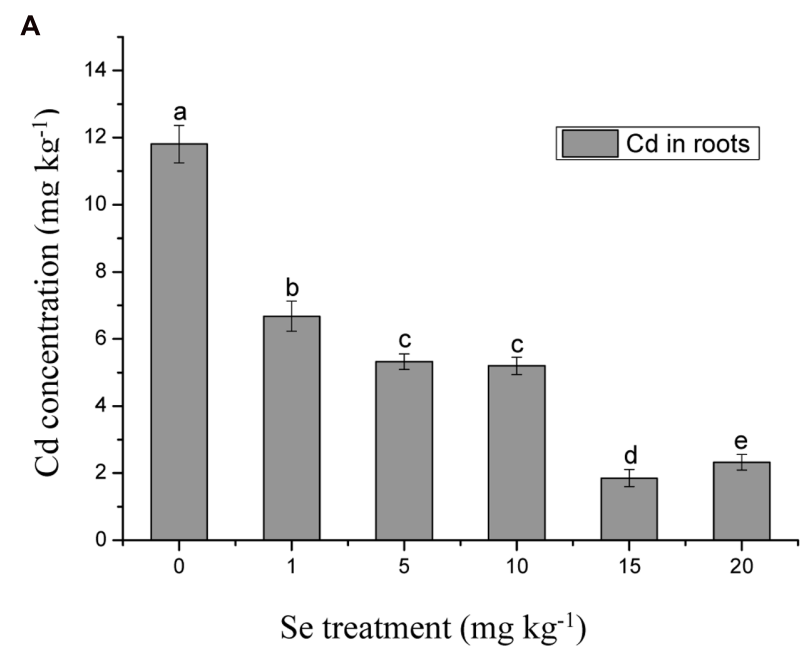

B

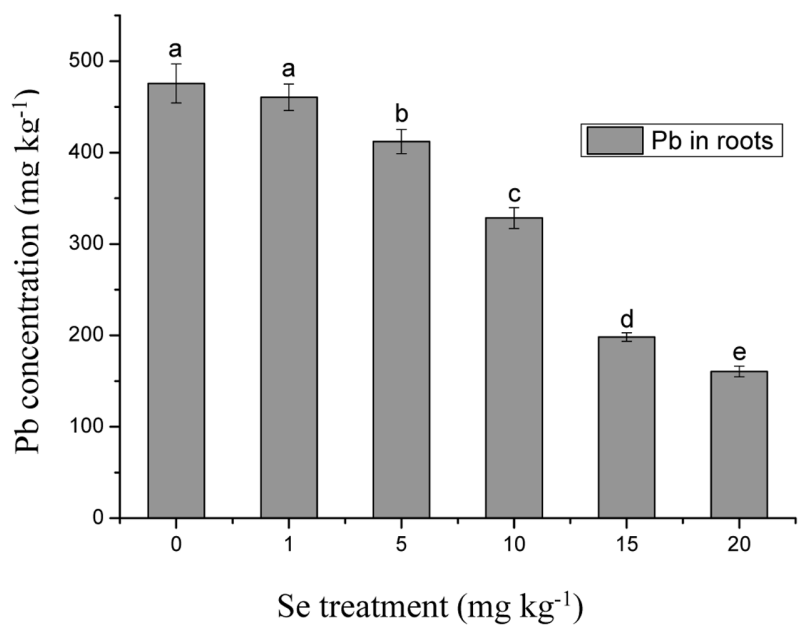

FIGURE 4 | (A) Concentration of $\mathrm{Cd}$ in roots of oilseed rape treated with soil Se and $5 \mathrm{mg} \mathrm{kg}^{-1} \mathrm{Cd}$ after a planting time of 60 days. (B) Concentration of $\mathrm{Pb}$ in roots of oilseed rape treated with soil Se and $500 \mathrm{mg} \mathrm{kg}^{-1} \mathrm{~Pb}$ after a planting time of 60 days. Average concentrations (Dry biomass weight, DBW) provided with error bars representing the standard error. Different letters mean significance of difference between the treatments $(p \leq 0.05)$.

2014; Qing et al., 2015). Selenium is primarily taken up from the soil by plants as selenate $\left(\mathrm{SeO}_{4}{ }^{2-}\right)$ or selenite $\left(\mathrm{SeO}_{3}{ }^{2-}\right)$, which is metabolized through the sulfate assimilation pathway and incorporated into multiple organic Se compounds (Hartikainen, 2005; Lin et al., 2012; Feng et al., 2013; Saidi et al., 2014; Qing et al., 2015). He et al. (2004) found that the addition of selenite to lettuce (Lactuca sativa L.) plants subjected to $\mathrm{Pb}$ and $\mathrm{Cd}$, significantly decreased the accumulation of these heavy metals and at the same time enhanced the uptake of some beneficial elements including Se. In this study, the Se concentrations of $15 \mathrm{mg} \mathrm{kg}^{-1}$ was the selective dosage for protecting oilseed rape from $\mathrm{Cd}$ and $\mathrm{Pb}$ toxicity. Moreover, $\mathrm{Cd}$ and $\mathrm{Pb}$ concentrations in the roots showed lower accumulation than that in the shoots, which may indicate that Se exerted antagonistic effects on Cdand $\mathrm{Pb}$-induced stresses in the roots (Figures $2-4$ ). In addition, 

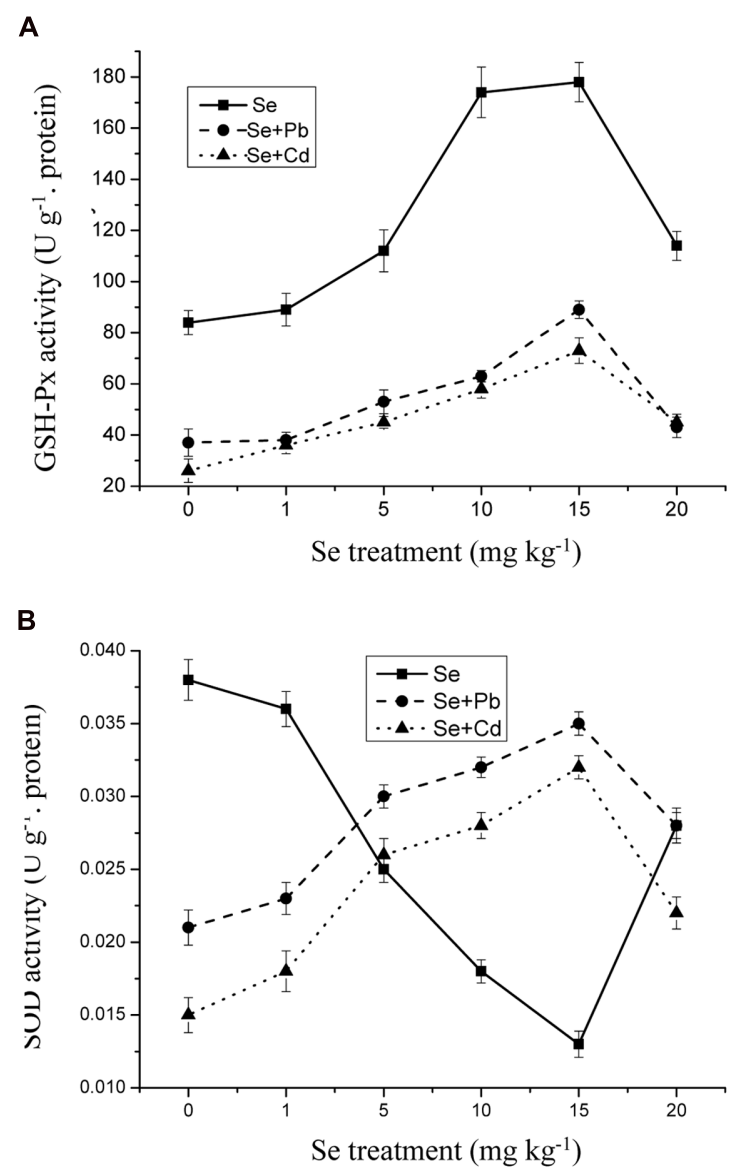

FIGURE 5 | (A) The activity of glutathione peroxidase (GSH-Px) in shoots of oilseed rape treated with soil $\mathrm{Se}, \mathrm{Se}+5 \mathrm{Cd}$, or $\mathrm{Se}+500 \mathrm{~Pb}$ after a planting time of 60 days. (B) The activity of superoxide dismutase (SOD) in shoots of oilseed rape treated with soil Se, Se+5Cd, or Se+500Pb after a planting time of 60 days. Average values (Fresh biomass weight, FBW) provided with error bars representing the standard error. $(p \leq 0.05)$.

plants have a range of potential mechanisms that may be involved in the detoxification of heavy metals. The mechanisms appear to be involved primarily in avoiding the buildup of toxic concentrations at sensitive sites within roots, thus, preventing plants from damaging effects (Lin et al., 2012; Feng et al., 2013; Saidi et al., 2014; Qing et al., 2015). The mechanisms induced by Se might be related to the inhibition of uptake and translocation of heavy metals from the roots to shoots and/or the speciation transformation of $\mathrm{Cd}$ and $\mathrm{Pb}$ to non-toxic species (Lin et al., 2012; Feng et al., 2013; Saidi et al., 2014; Qing et al., 2015). For example, Shanker et al. (1996c) suggested that Se possessed a strong ability to combine with heavy metals to form non-toxic Se-metal complexes in the soil-root environment. The current results provide strong evidence that Se can effectively alleviate $\mathrm{Cd} / \mathrm{Pb}$-induced growth inhibition, suggesting that, again, low levels of Se can exert beneficial effects on plants.

Oxidative stress is a key part of abiotic and biotic stresses (Feng et al., 2013; Saidi et al., 2014). This mechanism is caused by a serious cell damage by production of ROS, including

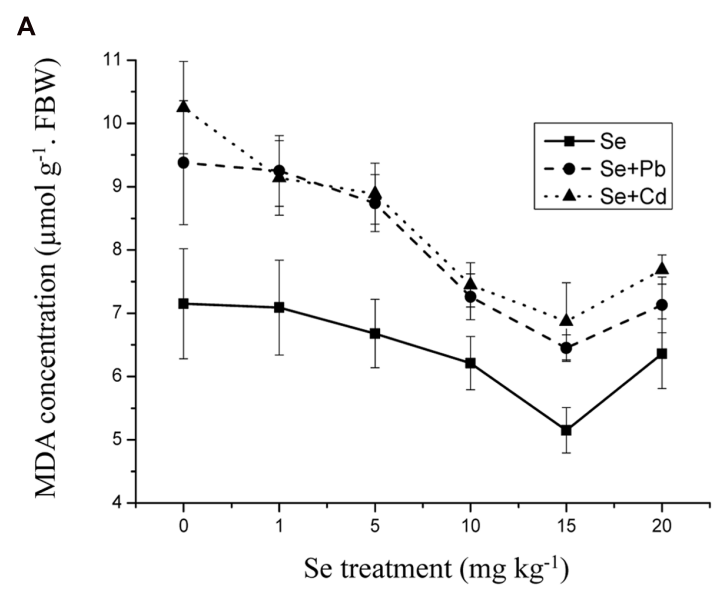

B

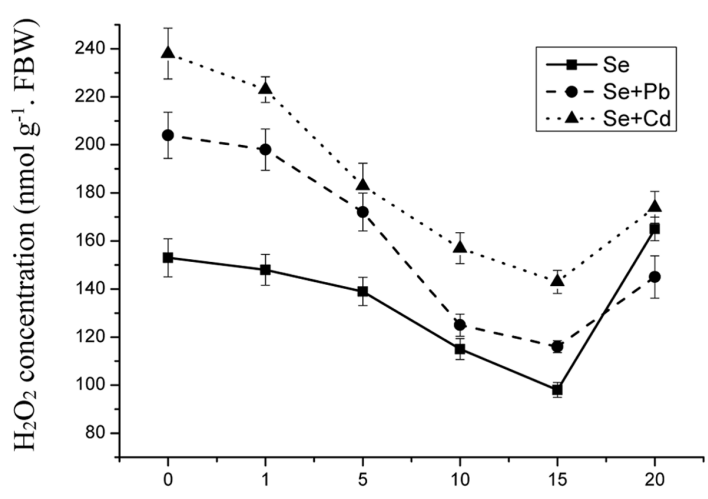

C Se treatment $\left(\mathrm{mg} \mathrm{kg}^{-1}\right)$

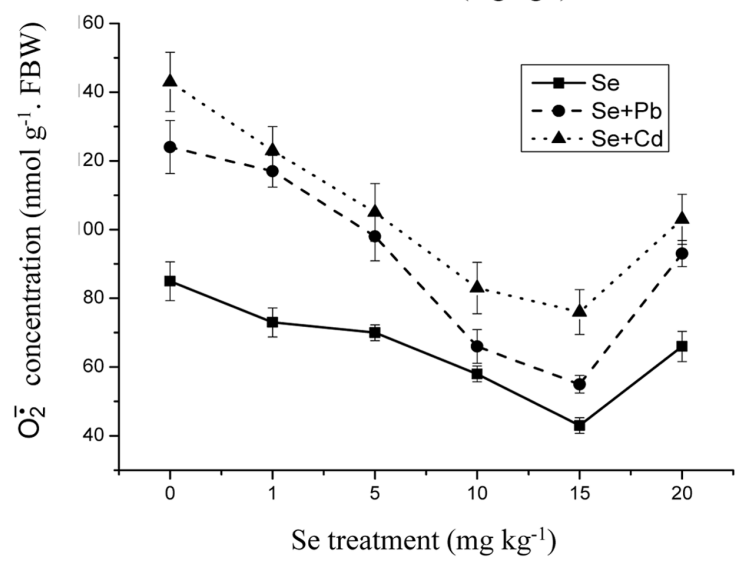

FIGURE 6 | (A) The concentration of malondialdehyde (MDA) in shoots of oilseed rape treated with soil $\mathrm{Se}, \mathrm{Se}+5 \mathrm{Cd}$, or $\mathrm{Se}+500 \mathrm{~Pb}$ after a planting time of 60 days. (B) The concentration of hydrogen peroxide $\left(\mathrm{H}_{2} \mathrm{O}_{2}\right)$ in shoots of oilseed rape treated with soil $\mathrm{Se}, \mathrm{Se}+5 \mathrm{Cd}$, or $\mathrm{Se}+500 \mathrm{~Pb}$ after a planting time of 60 days. (C) The productive rate of superoxide anion $\left(\mathrm{O}_{2}^{-}\right)$in shoots of oilseed rape treated with soil $\mathrm{Se}, \mathrm{Se}+5 \mathrm{Cd}$, or $\mathrm{Se}+500 \mathrm{~Pb}$ after a planting time of 60 days. Average values (Fresh biomass weight, FBW) provided with error bars representing the standard error. $(p \leq 0.05)$.

$\mathrm{O}_{2}^{\bar{a}}$ and $\mathrm{H}_{2} \mathrm{O}_{2}$, and antioxidative enzymes, which leads to dramatic physiological disorders. $\mathrm{Cd} / \mathrm{Pb}$-induced oxidative stress, reflected by increased MDA content, could be attributed to the increase of 
TABLE 1 | Selenium (Se) speciation in shoots of oilseed rape treated with soil Se, Se+Cd, or Se+Pb after a planting time of 60 days (Dry biomass weight, DBW).

\begin{tabular}{|c|c|c|c|c|c|}
\hline Treatments (mg kg $\left.{ }^{-1}\right)$ & Total Se $\left(\mathrm{mg} \mathrm{kg}^{-1}\right)$ & SeMet $\left(\mathrm{mg} \mathrm{kg}^{-1}\right)$ & $\mathrm{Se}^{4+}\left(\mathrm{mg} \mathrm{kg}^{-1}\right)$ & $\begin{array}{c}\text { SeMet as percentage } \\
\text { of total Se }\end{array}$ & $\begin{array}{c}\mathrm{Se}^{4+} \text { as percentage } \\
\text { of total } \mathrm{Se}\end{array}$ \\
\hline $15 \mathrm{Se}$ & $29.95 \pm 0.12 a$ & $2.584 \pm 0.05 a$ & 0 & $8.63 \%$ & 0 \\
\hline $15 \mathrm{Se}+300 \mathrm{~Pb}$ & $28.63 \pm 0.18 a$ & $5.473 \pm 0.04 b$ & $2.783 \pm 0.06$ & $19.12 \%$ & $9.72 \%$ \\
\hline $15 \mathrm{Se}+500 \mathrm{~Pb}$ & $25.92 \pm 0.14 a$ & $4.298 \pm 0.08 b$ & $1.225 \pm 0.03$ & $16.60 \%$ & $4.72 \%$ \\
\hline $15 \mathrm{Se}+1 \mathrm{Cd}$ & $26.58 \pm 0.25 a$ & $6.841 \pm 0.05 b$ & 0 & $25.74 \%$ & 0 \\
\hline $15 \mathrm{Se}+5 \mathrm{Cd}$ & $19.89 \pm 0.15 b$ & $5.447 \pm 0.06 b$ & 0 & $27.36 \%$ & 0 \\
\hline
\end{tabular}

All data show the means+SE of three replicates. Different letters mean significance of difference between the treatments ( $p \leq 0.05)$.

lipid peroxidation in plant cells (Lin et al., 2012; Saidi et al., 2014; Qing et al., 2015). The decreases in $\mathrm{O}_{2}^{-}$and $\mathrm{H}_{2} \mathrm{O}_{2}$ with addition of Se, suggest a disturbance of the ROS reaction chain, which diminishes the damage to the lipids of the plant cell membranes (Lin et al., 2012; Saidi et al., 2014; Qing et al., 2015). In this study, selenium supplementation has been shown to reduce $\mathrm{Cd} / \mathrm{Pb}$-induced oxidative stress as reflected by reduced $\mathrm{O}_{2}^{-}, \mathrm{H}_{2} \mathrm{O}_{2}$, and MDA (Figure 6). Therefore, our results suggest that the amelioration effects of Se on heavy metal stress are partly due to the improvement of scavenging capability of ROS, decrease in lipid peroxidation, and change in the membrane physicochemical characteristics, which increase plant cell integrity.

To scavenge ROS in cells and to avoid oxidative damage when exposed to abiotic or biotic stress, plants develop enzymatic, and non-enzymatic systems (Lin et al., 2012; Feng et al., 2013; Saidi et al., 2014; Qing et al., 2015). The present study has provided strong evidence of the protective role of Se against oxidative stress resulting from $\mathrm{Cd} / \mathrm{Pb}$ stress (Figures 5 and 6). The protective role appears to be responsible for beneficial effects of Se in terms of activation of shoot SOD and GPx during the entire treatment. However, supplementation of the medium with Se decreased $\mathrm{Cd} / \mathrm{Pb}$-induced high shoot SOD and GPx activity (Figure 5). The response of the SOD enzyme is closely related with Se, which was complicated when plants are stressed under various adverse environmental conditions in the presence of Se. At low stress levels, the antioxidative capacity in a plant should be sufficient to support the normal growth of the plant, while under a severe stress from exposure to heavy metals, high levels of ROS will be produced, and SOD activity is required. The enhancement in SOD activity might suggest the excess production of $\mathrm{O}_{2}^{\overline{0}}$ due to the toxicity of Se. The ROS production and quenching can thus be well controlled by antioxidants, resulting in the spontaneous reduction of $\mathrm{O}_{2}^{-}$and a reduced requirement for SOD (Shekhawat et al., 2010; Lin et al., 2012; Irfan et al., 2014; Saidi et al., 2014; Qing et al., 2015). In addition, GPx is a powerful scavenger of $\mathrm{H}_{2} \mathrm{O}_{2}$ and lipid hydroperoxides with the help of GSH in plants (Lin et al., 2012; Ali et al., 2015; Qing et al., 2015). GPx is believed to be a key enzyme that can be activated by Se in various plants exposed to diverse environmental stresses (Lin et al., 2012; Ali et al., 2015; Qing et al., 2015). In the presence of Se, GPx activity was enhanced compared to the group with heavy metals only. The increase in the activity of the GPx enzyme in response to the presence of Se suggests a unique role for this enzyme in counteracting oxidative stress in plants. Selenium-induced changes in the activity of oxidoreductase enzymes have been identified in some crops (Shekhawat et al., 2010; Lin et al., 2012; Irfan et al., 2014; Saidi et al., 2014; Qing et al., 2015). Selenium has synergistic effects on the transcription of antioxidative enzymes such as copper-zinc SOD (CuZnSOD) and GPx in plants, and promotes $\mathrm{H}_{2} \mathrm{O}_{2}$ scavenging by increasing GPx activity, which has been initially identified as an abiotic stress responsive enzyme (Shekhawat et al., 2010; Lin et al., 2012; Irfan et al., 2014; Saidi et al., 2014; Qing et al., 2015). From this study, we found that SOD activity was lower as a whole without heavy metals. Furthermore, the effects of Se accumulation on GPx and SOD activities are positive, while the effects of $\mathrm{Cd}$ and $\mathrm{Pb}$ on GPx and SOD activities are negative. SOD and GPx activities were depressed by both Cd and $\mathrm{Pb}$ exposure, while in other studies on Brassicaceae which enhanced by the same treatments (Lin et al., 2012; Qing et al., 2015). However, it needs more data to conclude the contribution of Se to the antioxidative system of $\mathrm{Cd}$ and $\mathrm{Pb}$ toxicity in oilseed rape plant. The use of scanning electron microscopy (SEM) and transmission electron microscopy (TEM) would be helpful for determining the effect of Se on inducing ultrastructural changes of oilseed rape plant tissues to heavy metal toxicity in oilseed rape plant.

In regards to Se speciation in plants, we can provide some possible mechanisms for the interactions of Se with heavy metals. Some crops convert Se mainly into SeMet and incorporate it into protein in place of methionine (Met) (Bañuelos et al., 2011; Persson et al., 2012, 2016a,b; Winkel et al., 2012; Yuan et al., 2013). In this study, the level of Se-Met was higher in the $\mathrm{Cd}$ and $\mathrm{Pb}$ treatments than in control, which suggests the protective role of $\mathrm{Se}$ against $\mathrm{Cd}$ and $\mathrm{Pb}$ toxicity might depend on the competition between Se and heavy metals for binding with the functional bioligands. Furthermore, the presence of $\mathrm{Cd}$ and $\mathrm{Pb}$ in the growth medium has a great effect on Se speciation transformed by plants, which might be also considered as one of the important conditions of Se-induced $\mathrm{Cd}$ and $\mathrm{Pb}$ tolerance in oilseed rape plants. Further studies are necessary to determine that distribution and speciation of Se in oilseed rape plant cells using synchrotron-based techniques, such as X-ray fluorescence and X-ray absorption spectrometry, and mass spectrometrybased techniques, such as secondary ion mass spectrometry and laser-ablation inductively coupled plasma mass spectrometry (Zhao et al., 2014; Persson et al., 2016a,b).

In addition, crop production is greatly influenced by abiotic stresses imposed by environmental factors such as heavy metals. A thorough understanding of plant response to heavy metals stress at the molecular level is very important for its effective 
management (Schützendübel and Polle, 2002). Therefore, further studies are required to elucidate the molecular mechanism for Se alleviating $\mathrm{Cd}$ and $\mathrm{Pb}$ toxicity in oilseed rape plant by omics approaches such as proteomics and metabolomics (Hesketh, 2008; Debnath et al., 2011; Hesketh and Méplan, 2011; Wang et al., 2013; Sinha et al., 2016). Specifically, Se is one of essential micronutrients for animals and human health but at high concentrations, widespread use of Se fertilization needs to be carefully evaluated in the context of potential ecological impacts because Se can become toxic to vertebrates.

\section{CONCLUSION}

In conclusion, the present results demonstrated that Se can reduce uptake of $\mathrm{Cd}$ and $\mathrm{Pb}$. This effect was especially observed when the growing medium was supplemented with Se at $15 \mathrm{mg}$ $\mathrm{kg}^{-1}$, which alleviated the negative effect of $\mathrm{Cd}$ and $\mathrm{Pb}$ on growth and led to a decrease in oxidative injuries caused by $\mathrm{Cd}$ and $\mathrm{Pb}$. The protective effect of $\mathrm{Se}$ in oilseed rape (B. napus L.) plants subjected to $\mathrm{Pb}$ and $\mathrm{Cd}$ exposure is complex. The mechanism involved in the prevention of $\mathrm{Cd}$ and $\mathrm{Pb}$ stress is mainly linked to both the inhibition of uptake and translocation of heavy metals from the roots to shoot and the reduction of oxygen radicials. Consequently, these results suggest that Se has antioxidant properties or that Se activates protective mechanisms that can alleviate oxidative stress in both enzymatic and nonenzymatic ways. Therefore, based on our results, we propose that the protective role of Se may be related to the decrease in lipid peroxidation, the improvement of scavenging capability of ROS, and the decrease in $\mathrm{Cd}$ and $\mathrm{Pb}$ uptake, transport and

\section{REFERENCES}

Ahmad, R., Waraich, E. A., Nawaz, F., Ashraf, M. Y., and Khalid, M. (2016). Selenium (Se) improves drought tolerance in crop plants-a myth or fact? J. Sci. Food Agric. 96, 372-380. doi: 10.1002/jsfa.7231

Ali, E., Maodzeka, A., Hussain, N., Shamsi, I. H., and Jiang, L. X. (2015). The alleviation of cadmium toxicity in oilseed rape (Brassica napus) by the application of salicylic acid. Plant Growth Regul. 75, 641-655. doi: 10.1007/ s10725-014-9966-0

Ardebili, N. O., Saadatmand, S., Niknam, V., and Khavari-Nejad, R. A. (2014). The alleviating effects of selenium and salicylic acid in salinity exposed soybean. Acta Physiol. Plant. 36, 3199-3205. doi: 10.1007/s11738-014-1686-6

Bañuelos, G. S., Fakra, S. C., Walse, S. S., Marcus, M. A., Yang, S. I., Pickering, I. J., et al. (2011). Selenium accumulation, distribution, and speciation in spineless prickly pear cactus: a drought- and salt-tolerant, selenium enriched nutraceutical fruit crop for biofortified foods. Plant Physiol. 155, 315-327. doi: 10.1104/pp.110.162867

Barton, L. L., and Abadia, J. (2006). Iron Nutrition in Plants and Rhizozpheric Microorganisms. Berlin: Springer, 129-151.

Belkhadi, A., Hediji, H., Abbes, Z., Nouairi, I., Barhoumi, Z., Zarrouk, M., et al. (2010). Effects of exogenous salicylic acid pre-treatment on cadmium toxicity and leaf lipid content in Linum usitatissimum L. Ecotoxicol. Environ. Saf. 73, 1004-1011. doi: 10.1016/j.ecoenv.2010.03.009

Belzile, N., Wu, G. J., Chen, Y. M., and Appanna, V. D. (2006). Detoxification of selenite and mercury by reduction and mutual protection in the assimilation of both elements by Pseudomonas fluorescens. Sci. Total Environ. 367, 704-714. doi: 10.1016/j.scitotenv.2006.03.008

Broadley, M. R., Alcock, J., Alford, J., Cartwright, P., Foot, I., Fairweather-Tait, S. J., et al. (2010). Selenium biofortification of high-yielding winter wheat (Triticum accumulation in plant tissues. Furthermore, the relevant $\mathrm{Cd}$ and $\mathrm{Pb}$ detoxification mechanisms by Se might be connected to the speciation transformation to non-toxic species.

\section{AUTHOR CONTRIBUTIONS}

ZW and ML wrote the main manuscript text, and ZW and ML prepared all figures and tables. GB and Z-QL revised the manuscript. XY and YL have provided input and assistance to the submission of the final manuscript. All authors reviewed the manuscript.

\section{ACKNOWLEDGMENTS}

The authors wish to thank Dr. Y.G. Zhu who comes from Institute of Ecology and Environment, Chinese Academy of Sciences for his useful comments and suggestions on our manuscript. This work was supported by the National Natural Science Foundation of China (Grant 31400091, 31401545, 50949038), the Natural Science Foundation of Anhui province (Grant 1408085MC68), Technology Innovation Fund by Institute of Advanced Technology, the University of Science and Technology of China (Grant 2013-1-16), the Natural Science Foundation of Jiangsu Province (Grant BK2012195 and BK2012202), and China Postdoctoral Science Foundation (Grant 20100470108 and 2013M540518). Moreover, authors would also like to thank the reviewers for their useful comments and suggestions in improving the quality of this manuscript.

aestivum L.) by liquid or granular Se fertilisation. Plant Soil 332, 5-18. doi: 10.1007/s11104-009-0234-4

Cao, F., Wang, N., Zhang, M., Dai, H., Dawood, M., Zhang, G., et al. (2013). Comparative study of alleviating effects of GSH, Se and Zn under combined contamination of cadmium and chromium in rice (Oryza sativa). Biometals 26, 297-308. doi: 10.1007/s10534-013-9611-9

Cartes, P., Jara, A. A., Pinilla, L., Rosas, A., and Mora, M. L. (2010). Selenium improves the antioxidant ability against aluminium-induced oxidative stress in ryegrass roots. Ann. Appl. Biol. 156, 297-307. doi: 10.1111/j.1744-7348.2010. 00387.x

Debnath, M., Pandey, M., and Bisen, P. S. (2011). An omics approach to understand the plant abiotic stress. OMICS 15, 739-762. doi: 10.1089/omi.2010.0146

Djanaguiraman, M., Devi, D. D., Shanker, A. K., Sheeba, J. A., and Bangarusamy, U. (2005). Selenium an antioxidative protectant in soybean during senescence. Plant Soil 272, 77-86. doi: 10.1007/s11104-004-4039-1

Djanaguiraman, M., Prasad, P. V. V., and Seppänen, M. (2010). Selenium protects sorghum leaves from oxidative damage under high temperature stress by enhancing antioxidant defense system. Plant Physiol. Biochem. 48, 999-1007. doi: 10.1016/j.plaphy.2010.09.009

Ellis, D. R., and Salt, D. E. (2003). Plants, selenium and human health. Curr. Opin. Plant Biol. 6, 273-279. doi: 10.1016/S1369-5266(03)00030-X

Feng, R., Wei, C., and Tu, S. (2013). The roles of selenium in protecting plants against abiotic stresses. Environ. Exp. Bot. 87, 58-68. doi: 10.1016/j.envexpbot. 2012.09.002

Filek, M., Keskinen, R., Hartikainen, H., Szarejko, I., Janiak, A., Miszalski, Z., et al. (2008). The protective role of selenium in rape seedlings subjected to cadmium stress. J. Plant Physiol. 165, 833-844. doi: 10.1016/j.jplph.2007.06.006

Filek, M., Kościelniak, J., Łabanowska, M., Bednarska, E., and Bidzńska, E. (2010). Selenium-induced protection of photosynthesis activity in rape (Brassica napus) 
seedlings subjected to cadmium stress. Fluorescense EPR measurements. Photosynth. Res. 105, 27-37. doi: 10.1007/s11120-010-9551-y

Gallego, S. M., Pena, L. B., Barcia, R. A., Azpilicueta, C. E., Iannone, M. F., Rosales, E. P., et al. (2012). Unravelling cadmium toxicity and tolerance in plants: insight into regulatory mechanisms. Environ. Exp. Bot. 83, 33-46. doi: 10.1016/j.envexpbot.2012.04.006

Germ, M., Kreft, I., and Osvald, J. (2005). Influence of UV-B exclusion and selenium treatment on photochemical efficiency of photosystem II, yield and respiratory potential in pumpkins (Cucurbita pepo L.). Plant Physiol. Biochem. 43, 445-448. doi: 10.1016/j.plaphy.2005.03.004

Grant, C. A., Clarke, J. M., Duguid, S., and Chaney, R. L. (2008). Selection and breeding of plant cultivars to minimize cadmium accumulation. Sci. Total Environ. 390, 301-310. doi: 10.1016/j.scitotenv.2007.10.038

Hall, J. L. (2002). Cellular mechanisms of heavy metal detoxification and tolerance. J. Exp. Bot. 53, 1-11. doi: 10.1093/jexbot/53.366.1

Han, D., Xiong, S. L., Tu, S. X., Liu, J. C., and Chen, C. (2015). Interactive effects of selenium and arsenic on growth, antioxidant system, arsenic and selenium species of Nicotiana tabacum L. Environ. Exp. Bot. 117, 12-19. doi: 10.1016/j. envexpbot.2015.04.008

Hanson, B., Garifullina, G. F., Lindblom, S. D., Wangeline, A., Ackley, A., Kramer, K., et al. (2003). Selenium accumulation protects Brassica juncea from invertebrate herbivory and fungal infection. New Phytol. 159, 461-469. doi: 10.1046/j.1469-8137.2003.00786.x

Hartikainen, H. (2005). Biogeochemistry of selenium and its impact on food chain quality and human health. J. Trace Elem. Med. Biol. 18, 309-318. doi: 10.1016/j. jtemb.2005.02.009

Hartikainen, H., Xue, T., and Piironen, V. (2000). Selenium as an anti-oxidant and pro-oxidant inryegrass. Plant Soil 225, 193-200. doi: 10.1023/A:1026512921026

Hasanuzzaman, M., and Fujita, M. (2011). Selenium pretreatment upregulates the antioxidant defense and methylglyoxal detoxification system and confers enhanced tolerance to drought stress in rapeseed seedlings. Biol. Trace Elem. Res. 143, 1758-1776. doi: 10.1007/s12011-011-8998-9

Hasanuzzaman, M., Hossain, M. A., and Fujita, M. (2011). Selenium induced upregulation of the antioxidant defense and methylglyoxal detoxification system reduces salinity induced damage in rapeseed seedlings. Biol. Trace Elem. Res. 143, 1704-1721. doi: 10.1007/s12011-011-8958-4

Hatfield, D. L., Tsuji, P. A., Carlson, B. A., and Gladyshev, V. N. (2014). Selenium and selenocysteine: roles in cancer, health, and development. Trends Biochem. Sci. 39, 112-120. doi: 10.1016/j.tibs.2013.12.007

He, P. P., Lv, X. Z., and Wang, G. Y. (2004). Effects of Se and Zn supplementation on the antagonism against $\mathrm{Pb}$ and $\mathrm{Cd}$ in vegetables. Environ. Int. 30, 167-172. doi: 10.1016/S0160-4120(03)00167-3

Hesketh, J. (2008). Nutrigenomics and selenium: gene expression patterns, physiological targets, and genetics. Annu. Rev. Nutr. 28, 157-177. doi: 10.1146/ annurev.nutr.28.061807.155446

Hesketh, J., and Méplan, C. (2011). Transcriptomics and functional genetic polymorphisms as biomarkers of micronutrient function: focus on selenium as an exemplar. Proc. Nutr. Soc. 70, 1-9. doi: 10.1017/S0029665111000115

Irfan, M., Ahmad, A., and Hayat, S. (2014). Effect of cadmium on the growth and antioxidant enzymes in two varieties of Brassica juncea. Saudi J. Biol. Sci. 21, 125-131. doi: 10.1016/j.sjbs.2013.08.001

Kaur, S., Kaur, N., Siddique, K. H. M., and Nayyar, H. (2016). Beneficial elements for agricultural crops and their functional relevance in defence against stresses. Arch. Agron. Soil Sci. 62, 905-920. doi: 10.1080/03650340.2015.1101070

Khan, M. I. R., Nazir, F., Asgher, M., Per, T. S., and Khan, N. A. (2015). Selenium and sulfur influence ethylene formation and alleviate cadmiuminduced oxidative stress by improving proline and glutathione production in wheat. J. Plant Physiol. 173, 9-18. doi: 10.1016/j.jplph.2014.09.011

Kumar, M., Bijo, A. J., Baghel, R. S., Reddy, C. R. K., and Jha, B. (2012). Selenium and spermine alleviates cadmium induced toxicity in the red seaweed Gracilaria dura by regulating antioxidant system and DNA methylation. Plant Physiol. Biochem. 51, 129-138. doi: 10.1016/j.plaphy.2011.10.016

Lin, L., Zhou, W. H., Dai, H. X., Cao, F. B., Zhang, G. P., and Wu, F. B. (2012). Selenium reduces cadmium uptake and mitigates cadmium toxicity in rice. J. Hazard. Mater. 235, 343-351. doi: 10.1016/j.jhazmat.2012.08.012

Malik, J. A., Goel, S., Kaur, N., Sharma, S., Singh, I., and Nayyar, H. (2012). Selenium antagonises the toxic effects of arsenic on mungbean (Phaseolus aureus Roxb.) plants by restricting its uptake and enhancing the antioxidative and detoxification mechanisms. Environ. Exp. Bot. 77, 242-248. doi: 10.1016/j. envexpbot.2011.12.001

Metwally, A., Finkemeier, I., Georgi, M., and Dietz, K. J. (2003). Salicylic acid alleviates the cadmium toxicity in barley seedlings. Plant Physiol. 132, 272-281. doi: 10.1104/pp.102.018457

Mozafariyan, M., Shekari, L., Hawrylak-Nowak, B., and Kamelmanesh, M. M. (2014). Protective role of selenium on pepper exposed to cadmium stress during reproductive stage. Biol. Trace Elem. Res. 160, 97-107. doi: 10.1007/s12011-0140028-2

Mroczek-Zdyrska, M., and Wojcik, M. (2012). The influence of selenium on root growth and oxidative stress induced by lead in Vicia faba L. minor plants. Biol. Trace Elem. Res. 147, 320-328. doi: 10.1007/s12011-011-9292-6

Noriega, G., Caggiano, E., Lecube, M. L., Cruz, D. S., Batlle, A., Tomaro, M., et al. (2012). The role of salicylic acid in the prevention of oxidative stress elicited by cadmium in soybean plants. Biometals 25, 1155-1165. doi: 10.1007/s10534012-9577-z

Pennanen, A., Xue, T. L., and Hartikainen, H. (2002). Protective role of selenium in plant subjected to severe UV irradiation stress. J. Appl. Bot. 76, 66-76.

Persson, D. P., Chen, A., Aarts, M. G., Salt, D. E., Schjoerring, J. K., and Husted, S. (2016a). Multi-element bioimaging of Arabidopsis thaliana roots. Plant Physiol. doi: 10.1104/pp.16.00770 [Epub ahead of print].

Persson, D. P., de Bang, T. C., Pedas, P. R., Kutman, U. B., Cakmak, I., Andersen, B., et al. (2016b). Molecular speciation and tissue compartmentation of zinc in durum wheat grains with contrasting nutritional status. New Phytol. 211, 1255-1265. doi: 10.1111/nph.13989

Persson, D. P., Hansen, T. H., Laursen, K. H., Husted, S., and Schjoerring, J. K. (2012). ICP-MS and LC-ICP-MS for analysis of trace element content and speciation in cereal grains. Methods Mol. Biol. 860, 193-211. doi: 10.1007/9781-61779-594-7_13

Pezzarossa, B., Remorini, D., Gentile, M. L., and Massai, R. (2012). Effects of foliar and fruit addition of sodium selenate on selenium accumulation and fruit quality. J. Sci. Food Agric. 92, 781-786. doi: 10.1002/jsfa.4644

Pilon-Smits, E. A. H., Quinn, C. F., Tapken, W., Malagoli, M., and Schiavon, M. (2009). Physiological functions of beneficial elements. Curr. Opin. Plant Biol. 12, 267-274. doi: 10.1016/j.pbi.2009.04.009

Popova, L. P., Maslenkova, L. T., Yordanova, R. Y., Ivanova, A. P., Krantev, A. P., Szalai, G., et al. (2009). Exogenous treatment with salicylic acid attenuates cadmium toxicity in pea seedlings. Plant Physiol. Biochem. 47, 224-231. doi: 10.1016/j.plaphy.2008.11.007

Pukacka, S., Ratajczak, E., and Kalembam, E. (2011). The protective role of selenium in recalcitrant Acer saccharium L. seeds subjected to desiccation. J. Plant Physiol. 168, 220-225. doi: 10.1016/j.jplph.2010.07.021

Qing, X., Zhao, X., Hu, C., Wang, P., Zhang, Y., Zhang, X., et al. (2015). Selenium alleviates chromium toxicity by preventing oxidative stress in cabbage (Brassica campestris L. ssp. Pekinensis) leaves. Ecotoxicol. Environ. Saf. 114, 179-189. doi: 10.1016/j.ecoenv.2015.01.026

Rayman, M. P. (2000). The importance of selenium to human health. Lancet 356, 233-241. doi: 10.1016/S0140-6736(00)02490-9

Saidi, I., Chtourou, Y., and Djebali, W. (2014). Selenium alleviates cadmium toxicity by preventing oxidative stress in sunflower (Helianthus annuus) seedlings. J. Plant Physiol. 171, 85-91. doi: 10.1016/j.jplph.2013.09.024

Schützendübel, A., and Polle, A. (2002). Plant responses to abiotic stresses: heavy metal-induced oxidative stress and protection by mycorrhization. J. Exp. Bot. 53, 1351-1365. doi: 10.1093/jexbot/53.372.1351

Shanker, K., Mishra, S., Srivastava, S., Srivastava, R., Daas, S., Prakash, S., et al. (1996a). Effect of selenite and selenate on plant uptake and translocation of mercury by tomato (Lycopersicum esculentum). Plant Soil 183, 233-238. doi: 10.1007/BF00011438

Shanker, K., Mishra, S., Srivastava, S., Srivastava, R., Daas, S., Prakash, S., et al. (1996b). Effect of selenite and selenate on plant uptake of cadmium by maize (Zea mays). Bull. Environ. Contam. Toxicol. 56, 419-424. doi: 10.1007/ s001289900060

Shanker, K., Mishra, S., Srivastava, S., Srivastava, R., Daas, S., Prakash, S., et al. (1996c). Study of mercury-selenium (Hg-Se) interactions and their impact on Hg uptake by the radish (Raphanus sativus) plant. Food Chem. Toxicol. 34, 883-886. doi: 10.1016/S0278-6915(96)00047-6

Shekhawat, G. S., Verma, K., Jana, S., Singh, K., Teotia, P., and Prasad, A. (2010). In vitro biochemical evaluation of cadmium tolerance mechanism in callus and 
seedlings of Brassica juncea. Protoplasma 239, 31-38. doi: 10.1007/s00709-0090079-y

Sinha, I., Karagoz, K., Fogle, R. L., Hollenbeak, C. S., Zea, A. H., Arga, K. Y., et al. (2016). "Omics" of selenium biology: a prospective study of plasma proteome network before and after selenized-yeast supplementation in healthy men. OMICS 20, 202-213. doi: 10.1089/omi.2015.0187

Srivastava, S., Shanker, K., Srivastava, S., Srivastav, R., Das, S., Prakash, S., et al. (1998). Effect of selenium supplementation on the uptake and translocation of chromium by spinach (Spinacea oleracea). Bull. Environ. Contam. Toxicol. 60, 750-758. doi: 10.1007/s001289900690

Su, Y., Liu, J. L., Lu, Z. W., Wang, X. M., Zhang, Z., and Shi, G. R. (2014). Effects of iron deficiency on subcellular distribution and chemical forms of cadmium in peanut roots in relation to its translocation. Environ. Exp. Bot. 97, 40-48. doi: 10.1016/j.envexpbot.2013.10.001

Tang, H., Liu, Y. G., Gong, X. M., Zeng, G. M., Zheng, B. H., Wang, D. F., et al. (2015). Effects of selenium and silicon on enhancing antioxidative capacity in ramie (Boehmeria nivea (L.) Gaud.) under cadmium stress. Environ. Sci. Pollut. Res. 22, 9999-10008. doi: 10.1007/s11356-015-4187-2

Terry, N., Zayed, A. M., De Souza, M. P., and Tarun, A. S. (2000). Selenium in higher plants. Annu. Rev. Plant Physiol. Plant Mol. Biol. 51, 401-432. doi: 10.1146/annurev.arplant.51.1.401

Trumble, J. T., Kundm, G. S., and White, K. K. (1998). Influence of form and quantity of selenium on the development and survival of an insect herbivore. Environ. Pollut. 101, 175-182. doi: 10.1016/S0269-7491(98)00086-4

Turakainen, M., Hartikainen, H., and Seppanen, M. M. (2004). Effects of selenium treatments on potato (Solanum tuberosum L.) growth and concentrations of soluble sugars and starch. J. Agric. Food Chem. 52, 5378-5382. doi: 10.1021/ jf040077x

Wang, Y. D., Wang, X., Ngai, S. M., and Wong, Y. S. (2013). Comparative proteomics analysis of selenium responses in selenium-enriched rice grains. J. Proteome Res. 12, 808-820. doi: 10.1021/pr300878y

Winkel, L. H., Johnson, C. A., Lenz, M., Grundl, T., Leupin, O. X., Amini, M., et al. (2012). Environmental selenium research: from microscopic processes to global understanding. Environ. Sci. Technol. 46, 571-579. doi: 10.1021/es203 $434 \mathrm{~d}$

Wu, Z. L., Bañuelos, G. S., Lin, Z. Q., Liu, Y., Yuan, L. X., Yin, X. B., et al. (2015). Biofortification and phytoremediation of selenium in China. Front. Plant Sci. 6:136. doi: 10.3389/fpls.2015.00136
Wu, Z. L., Yin, X. B., Bañuelos, G. S., Lin, Z. Q., Zhu, Z., Liu, Y., et al. (2016). Effect of selenium on control of postharvest gray mold of tomato fruit and the possible mechanisms involved. Front. Microbiol. 6:1441. doi: 10.3389/fmicb.2015.01441

Xue, T. L., Hartikainen, H., and Piironen, V. (2001). Antioxidative and growthpromoting effect of selenium on senescing lettuce. Plant Soil 237, 55-61. doi: 10.1023/A:1013369804867

Yao, X. Q., Chu, J. Z., and Ba, C. J. (2010). Antioxidant responses of wheat seedlings to exogenous selenium supply under enhanced ultraviolet-B. Biol. Trace Elem. Res. 136, 96-105. doi: 10.1007/s12011-009-8520-9

Yathavakilla, S. K. V., and Caruso, J. A. (2007). A study of Se-Hg antagonism in Glycine max (soybean) roots by size exclusion and reversed phase HPLC-ICPMS. Anal. Bioanal. Chem. 389, 715-723. doi: 10.1007/s00216-0071458-X

Yuan, L. X., Zhu, Y. Y., Lin, Z. Q., Banuelos, G., Li, W., and Yin, X. B. (2013). A novel selenocystine-accumulating plant in selenium-mine drainage area in Enshi, China. PLoS ONE 8:6. doi: 10.1371/journal.pone.0065615

Zembala, M., Filek, M., Walas, S., Mrowiec, H., Kornas, A., Miszalski, Z., et al. (2010). Effect of selenium on macro- and microelement distribution and physiological parameters of rape and wheat seedlings exposed to cadmium stress. Plant Soil 329, 457-468. doi: 10.1007/s11104-009-0171-2

Zhao, F. J., Moore, K. L., Lombi, E., and Zhu, Y. G. (2014). Imaging element distribution and speciation in plant cells. Trends Plant Sci. 19, 183-192. doi: 10.1016/j.tplants.2013.12.001

Zhu, Y. G., Pilon-Smits, E. A. H., Zhao, F. J., Williams, P. N., and Meharg, A. A. (2009). Selenium in higher plants: understanding mechanisms for biofortification and phytoremediation. Trends Plant Sci. 14, 436-442. doi: 10. 1016/j.tplants.2009.06.006

Conflict of Interest Statement: The authors declare that the research was conducted in the absence of any commercial or financial relationships that could be construed as a potential conflict of interest.

Copyright (c) 2016 Wu, Yin, Bañuelos, Lin, Liu, Li and Yuan. This is an open-access article distributed under the terms of the Creative Commons Attribution License (CC BY). The use, distribution or reproduction in other forums is permitted, provided the original author(s) or licensor are credited and that the original publication in this journal is cited, in accordance with accepted academic practice. No use, distribution or reproduction is permitted which does not comply with these terms. 